\title{
The Eternal Return: The Heaviest of the Burdens
}

\author{
Fatemeh (Sara) Pakdamanshahri \\ PhD Candidate Yeditepe University, \\ Istanbul, Turkey
}

\begin{abstract}
"Putting it negatively, the myth of eternal return states that a life which disappears once and for all, which does not return, is like a shadow, without weight, dead in advance, and whether it was horrible, beautiful, or sublime, its horror, sublimity, and beauty mean nothing." 1 As Kundera, himself, puts it, the idea of living once and never returning to it suggests the utmost lightness under which one's existence hinders rather than strengthen. The Unbearable Lightness of Being calls on us in the hope of a rediscovery of the experience of homecoming, not only in a geographical sense as we see in Oedipus the King, but more importantly in the psychological, spiritual, and epistemological sense of the term. The struggle between fate and freedom of choice, feeling of guilt and the resolution to its confrontation are among the mutual themes in these two literary masterpieces. Although there are a number of one to one connections between certain characters in the two literary works mentioned, the noteworthy is the individual journey they take to return home (in its metaphorical sense), which at the same time speaks of a collective journey of the homecoming of the human being.
\end{abstract}

Key words: Milan Kundera, Oedipus, Journey, self, homecoming, Heidegger, Nietzsche

\section{INTRODUCTION}

Tomas, the protagonist of the novel, an almost middle-aged well-known surgeon whose livelihood depends greatly on his erotic relationships with women, is proud of and comfortable with what he defines lightness of his life. His dilemma is of a never-ending nature. Johan Degenaar recounts a quotation from Kundera: "There are various examples of Tomas as a character of doubt. I have mentioned his inability to make up his mind concerning the choice between his life-style of erotic friendships and compassion for Tereza, between desiring one and leaving one. Tomas asks himself: "Why should one have to choose?"2

Tomas' struggle to choose one, as he is very well aware that to choose one entails admitting to self-knowledge takes on a good portion of the narrative. Eventually, though he decides to undertake the journey until the very end of it. Likewise, Oedipus recognizes himself as a man of wisdom, a figure who knows of his own virtues and vices. The difference between the two falls on the moment of epiphany, the revelation which happens with the modern Tomas, and unfortunately escapes the ancient king.

This paper intends to discuss the theme of eternal homecoming in Oedipus Rex and The Unbearable Lightness of Being through the theories of Nietzche and Heidegger. The universal struggle between escaping and acceptance of the truth and its consequences, the homecoming of the protagonist, of the humankind.

\footnotetext{
${ }^{1}$ Milan Kundera, The unbearable Lightness of Being, trans. by Michael Henry Heim, (London: Faber \& Faber: 2015), 1.

${ }^{2}$ Johan Degenaar, "The unbearable Lightness of Being-a Philosophical Exploration in Literator" in Journal of Literary Criticism, Comparative Linguistics and Literary Studies, Volume III, ( Nov. 1992), 57.
} 


\section{The Theme of Homecoming, Campbell}

The concept of homecoming in the mythological sense of the word has long been tended to. Joseph Campbell's model of the final step of the myth is among the most recognizable: "When the heroquest has been accomplished, through penetration to the source, or through the grace of some male or female, human or animal, personification, the adventurer still must return with his life-transmuting trophy." 3 Let us note that what Campbell is concerned with is the stage the hero goes through once the departure, initiation, return in its life-transforming sense is over. He further explains: "Once the hero finally accomplishes his homecoming and returns home the adventure is understood to have come to a close. In these typical 'hero myths' home appears as a place of belonging and sanctuary where the returning hero is warmly welcomed." 4 What Campbell wants us to see is the crucial status of returning home as a return to a sanctuary, where the hero belongs.

\section{The Theme of Homecoming in Nietzsche and Heidegger's Idea}

Now let us delve into Nietzche's definition of the concept of homecoming in The Gay Science.

"What if some day or night a demon were to steal after you into your loneliest loneliness and say to you: 'This life as you now live it and have lived it, you will have to live once more and innumerable times more'... would you throw yourself down and gnash your teeth and curse the demon who spoke thus? Or have you once experienced a tremendous moment when you would have answered him: 'You are a god and never have I heard anything more divine?'”5

What he meant by reliving one's life innumerable times was the idea that one needs to make a decision at a certain stage of one's life whether their life is worth reliving. It is the same concept Kundera refers to at the beginning of the novel: '...the myth of eternal return states that a life which disappears once and for all, which does not return is like a shadow, without weight, dead in advance, and whether it was horrible, beautiful, or sublime, its horror, sublimity, and beauty mean nothing." $\mathrm{A}$ few steps further the narrator in Kundera's novel asks: "Will the war between two African kingdoms in the fourteenth century itself be altered if it recurs again and again, in eternal return?"7

Nietzsche wants us to make a U-turn towards ourselves and ask ourselves a question, an existential question. A sort of existential question that requires an utmost level of selfknowledge, self-awareness and belief in freedom of choice, a belief that allows individuals to hold themselves responsible for their choices and the turn of events in their lives and the course of their lives, including the sorrows and joys, the miseries and turmoils needs to be posed to us by us. It is on each and every one of us to examine our lives and continue to live merely and merely under the condition that we are willing to relive each and every moment of that life over and over and consider it the sanest idea of all as he mentions, the most "divine".

Heidegger refers to Thus Spake Zarathustra to highlight the concept of a being called "The Convalescent". Heidegger remarks:

"Toward the end of the third part of Thus spake Zarathustra, appears a section with the heading 'The Convalescent'. That is Zarathustra. But what does 'convalescent', der Genesende, mean? Genesen is the same word as the Greek neomai, nostos, meaning to lead home.

\footnotetext{
3 Joseph Campbell, The Hero With a Thousand Faces, (Princeton: Princeton University Press, 1949), 193.

4 Ibid, 195.

${ }^{5}$ Friedrich Nietzsche, The Gay Science, trans. by Walter Kaufmann (New York: Vintage Books, 1974), 340.

${ }^{6}$ Milan Kundera, The unbearable Lightness of Being, 1.

7 Ibid, 5.
} 
'Nostalgia' is the yearning to go home, homesickness. 'The Convalescent' is one who is getting ready to turn homeward, that is, to turn toward what defines him. The convalescent is under way to himself, so that he can say of himself who he is."8

Heidegger thereby clarifies the parameters of this specific being defined by Nietzche, she is the one who is aware enough to have realized that there exists no home but the home within oneself, the knowing of oneself. According to these rather metaphysical concepts posed by Nietzche and Heidegger, an autonomous individual is to make a journey towards herself, face herself, know herself, and decide if the life she is leading is worth living innumerable times.

Believing in what was elaborated, there is no physical sense in the concept of homecoming but the knowing and acceptance of what one is, which then puts us under the burden of an immeasurable responsibility, which Kundera calls "heaviness".

\section{HOMECOMING IN OEDIPUS REX ACCORDING TO CAMPBELL'S MODEL}

According to Campbell's model, the hero starts his journey in order to achieve a desired outcome, which in Oedipus's case is not turning out to be a murderer; a prophecy he felt entrapped in. He flees Corinth in this hope, gets into an avoidable fight and kills Laius, the hardship to deal with to grow according to the traditional model of the myth of homecoming would be to avoid acting upon his arrogance and consequently murdering a human being. He, himself does admit that the one and only reason for murdering Laius has been rage. $\mathrm{He}$ recounts how he committed the murder.

Oedipus And then a herald come towards me, and a chariot

Drawn by horses, with a man such as you describe

Seated in it. The groom leading the horses

Forced me off the road at his Lord's command;

But as this charioteer lurched over towards me

I struck him in my rage. The old man saw me

And brought his double goad down upon my head

As I come abreast.

He was paid back and more!

Swinging my club in this right hand I knocked him

Out of his car, and he rolled on the ground

I killed him.

Why the old man must have been paid more, remains a mystery, a foul act, with which Oedipus would be the only living soul feels content. He could have easily avoided the manslaughter, had he not been blatantly arrogant.

He uses his intellect, solves the Sphinx's riddle, saves the city. It is crucial for us not to neglect the fact that Oedipus is not an ordinary being, specifically in the world of ancient Greece. He belongs to the arena of semi-humanly semi-godly attributes, as the priest puts it:

Priest ... you saved us

From the Sphinx, that flinty singer, and the tribute

We paid to her so long; yet you were never

Better informed than we, nor could we teach you:

A god's touch, it seems, enabled you to help us. ${ }^{9} \quad$ (I. 38-42)

${ }^{8}$ Martin Heidegger, Nietzsche, Vol II, trans. by David Farrell Krell, (San Francisco: Harper Collins, 1979-1987), 212.

${ }_{9}^{9}$ Sophocles, Oedipus The King, trans. Dudley Fitts and Robert Fitzgerald, (California: Harcourt Inc.: 1977) 
We are thus speaking of Oedipus, a hero specifically praised for his god-like wisdom both within and outside the fictional world. And yet it fails him when it comes to going home, towards his being, his essence. The very first sign of his inadequate knowledge is a dramatic irony pictured through his words when he addresses the citizens of Thebes in sympathy:

Oedipus Sick as you are, not one is as sick as I.

(I. 63)

One is to interpret the dialogues and styles of the fictional world considering the genre and the context as Olsen remarks in regard with Oedipus's ability to see and Teiresias's blindness: "Consider the agon between Teiresias and Oedipus in King Oedipus, where there is a number of superficial paradoxes and some for reaching irony: the blind man who can see the truth, the seeing man who is blind to it."10 As for Oedipus's words above, it is the pure truth that he is the manifestation of sickness itself, he is completely unaware of it.

Oedipus, undoubtedly enjoys the power given to him as the king of Thebes, his ego is well-fed, so fully fed that even the thought of facing the consequences his evil deeds turns him into a foul speaking figure. He has got to deflect what he senses on a deeper level of himself to the one devoid of guilt:

Oedipus Suppose the oracle had given you no command

Should this defilement go uncleansed for ever?

You should have found the murderer; your king,

A noble king, had been destroyed!

(II. 38-41)

The responsibility he is condemning the whole Thebes of ignoring lies on his shoulders as well. Was he not to questions the absence of the king once he entered the city triumphantly to bear the throne on his head?

It no doubt has been left in the hands of the hero to be worthy and if not become worthy of being welcomed to his home on the verge of homecoming. Oedipus was certainly held responsible to have made himself deserving of Thebes's open arms to hold him unconditionally henceforth. His disregard for the life of another is the tie he himself has put on the hands of home, Thebes, to never again welcome him. It is a simple equation, our godly hero is not welcomed to the eternal sanctuary he originally belongs to since he fails his initiation, since he prioritizes the life of some over the life of others. The murdering of a stranger is nothing to him, and thus he fails to achieve a certain maturity that is expected from him as Lee Morgan et. All clarify: "The hero undergoes a series of excruciating ordeals in passing from ignorance and immaturity to social and spiritual adulthood, that is, in achieving maturity and becoming a fullfledged member of his or her social group... Like the quest, this is a variation of the death-andrebirth archetype."11 Oedipus does not succeed in shedding the ignorance cloak in order to return home, instead, he condemns himself of eternal homelessness.

According to Campbell's model, Thebes never turns into the sanctuary it is expected to become, as Oedipus never allows it to be, he deprives himself of returning to a home he deserved had he not murdered a human being and had he not felt victorious in succession. He has no choice but to rid himself of his immaturity and arrogance, to face his blindness as opposed to Teiresias's wisdom and is left with no choice but to exile himself. Oedipus does not succeed in getting

\footnotetext{
10 Stein Haugom Olsen, "The Meaning of a Literary Work" in New Literary History, Problems of Literary Theory, Vol. 12, No. 1, (Baltimore: John Hopkins University Press: 1982), 27.

${ }^{11}$ Jeanne Campbell Reesman, John R. Willingham, Lee Morgan, Earle Labor, Wilfred L. Guerin, A Handbook of Critical approaches to Literature, (New York: Oxford university Press, 2005), 184.
} 
home in the peaceful sense of the myth, he does return to his geographical origin, however, tragically. Ahl provides us with a rather inclusive reading of not only Oedipus's existential failure but rather every other human being.

"We readers [of Sophocles' Oedipus] may become Oedipus like if we assume that the myth is a "given", that it is "fate", and that the hero, the self, is the only character who has motives and ambitions. We can remain as oblivious to its [the play's] pluralism as Oedipus. But we do not have to."12

\section{HOMECOMING IN OEDIPUS REX ACCORDING TO NIETZSCHE AND HEIDEGGER'S MODEL}

Considering Oedipus the King based on the thoughts of Nietzche and Heidegger, Oedipus starts his journey towards self-knowledge, although unconsciously and unknowingly. He does so initially to avoid fulfilling the prophecy. Eventually, he ends up doing the unspeakable deeds and then comes the time to face the consequences, the moment of truth. His lack of awareness manifests itself brazen when it comes to him showing his commitment to disposing of the plague surrounding Thebes.

Kreon Then I will tell you what I heard at Delphi

In plain words

The god commands us to expel from the land of Thebes

An old defilement we are sheltering

It is a deathly thing beyond cure;

We must not let it feed upon us longer. $\quad$ (I. 97-102)

The one beyond cure is no doubt Oedipus himself. Alas, he is blind to the defilement he carries within his heart as Griffith puts it: "This man, who knows of his ignorance, acts not once but repeatedly as though he were privy even to hidden facts, treating the many phantasms of his imagination, as though they were manifest revelations." 13

Further on his response is:

Oedipus Then once more I must bring what is dark to light. (I. 134)

What he says not only is another perfect example of the dramatic irony of how far he is from the true essence of his existence and his deeds, but it points out the fact that when it comes to "bringing dark to light" of any sort, he would be the last person to call on.

He is determined in his new mission -ridding Thebes of evil- by all means even if it entails unshielding someone akin to himself.

Oedipus: And as for me, this curse applies no less

If it should turn out that the culprit is my guest here,

Sharing my hearth.

(II. 2-34)

He, assuredly shows his sense of justice, his utmost loyalty to the truth. Nothing matters to him when it comes to the saving of the people of Thebes and Thebes itself, even if they should share the same "hearth", -the murderer and Oedipus. Yet this sense of justice and his loyalty to it lasts only in the condition that he is not the one under scrutiny. Once Teiresias reveals the truth to him, comes another act of deflection since he cannot bear to see the real essence of himself. He accuses Kreon of having asked Teiresias to lie to bring him a kingdom to doom.

12 Frederick Ahl, Sophocles' Oedipus: Evidence and Self Conviction, (London: Cornell University Press, 1991 ), 262.

13 R. Drew Griffith, Asserting Eternal Providence: Theodicy in Sophocles' "Oedipus the King”, in Illinois Classical Studies, Vol. 17, No. 2, (Fall 1992), pp. 193-211, 204. 
Oedipus Tell me, in God's name: am I a coward, a fool,

That you should dream you could accomplish this?

A fool who could not see your slippery game?

A coward not to fight back when I saw it?

(II. 24-7)

It is more than ironic. It is tragic that he takes himself for no fool or a coward, and yet he embodies them both. Oedipus is a fool, as he refuses to accept the knowledge at hand, and a coward, since he has feared to lose his life so much that he murdered Laius and approached the prophecy with sheer apprehension that he was only capable of anticipating an escape from Corinth. And yet again he parades his sense of justice once he dreams of others as being the subjects to it. He thinks Kreon has attempted an act of treason, which deserves to be dealt with nothing but justice:

Oedipus If you think a man can sin against his own kind

And not be punished for it, I say you are mad.

(II. 39-40)

One of the factors that places Oedipus far from the vicissitude of being a 'Convalescent' is his indecisiveness in him being free or in the boundaries of gods. It is clear that he has decided to flee Corinth since he believes in fate, and what has been written for him by the gods. And yet, many times he holds himself responsible for having set Thebes free from the evils of the Sphinx. He refers to his supposedly heroic act once he says:

Oedipus Then once more I must bring what is dark to light.

(I. 134)

Clearly, he says "once more" as he believes that he has done it before. He considers himself capable of godly acts.

However, once he finds out about his murdering his father, he blames the gods again:

Oedipus If I was created so, born to this fate,

Who could deny the savagery of God?

(II. 303-4)

And he never succeeds in admitting to himself that the murder has not been the only option, as Griffith puts it: "Likewise at the crossroads, he acted -knowingly and yet as though unknowingly- in ignorance recklessly failing to yield when it was moral and convenient to do so." ${ }^{14}$ There is no other explanation for a human being who regards himself of having the power of bringing a whole city from darkness to light twice, as many times as it takes for that matter, and yet believes that it was on the "savagery" of God that had brought him to such a misery and wretchedness. Oedipus fails himself in knowing himself.

Once again he believes he is damned; that is, it has not been him behind the wheel, but the fate that has brought his downfall.

Oedipus O Light, may I look on you for the last time!

I, Oedipus,

Oedipus damned in his birth, in his marriage damned,

Damned in the blood he shed with his own hand!

(IV. 70-73)

14 Ibid, 205. 
He has got to go on exile as if the journey for him has got to start so that he could look within and find out why he has done so rather than merely obsessing over what he has done. He has acted upon his fear. He has been extremely arrogant to have committed a murder from which there was an easy way out, staying off the road and letting the arrogant roam it.

Is this a life he would be willing to live innumerable times in Nietzchian sense of eternal return? Would he be able to justify to himself that his life is worth living over and over? I believe not. The question of choosing heaviness over lightness or otherwise is made clear by Oedipus himself:

Oedipus If only I had died,

This weight of monstrous doom

Could not have dragged me and my darlings down.

(IV. 128-130)

Oedipus's final words so vividly expose the audience to the fact that in Heideggerian sense of the myth of homecoming, Oedipus never succeeds in telling himself who he is:

Oedipus For I am sick

In my own being, sick in my origin.

(IV. 170-1)

In a modern world with a modern worldview, one does realize that no one is sick in their origin unless they have willingly blinded themselves and blamed their fate for their doings and being. Ahl concludes Oedipus's state of mind artistically:

"Although it would be hard, if not impossible, to argue that Oedipus is entirely innocent (the scars on his ankle suggest otherwise), it should be clear from the above examples that Sophocles' play is as much about his ultimate self-deception as it is about his final self-discovery. Through his rash judgments, Oedipus allows others -the drunk at the banquet, Creon, Teiresias, the messenger- to define his identity and his past. He is thus, responsible for the outcome, not because of a definitely proven guilt, but because he resigns the freedom of self-determination, opting to accept others' versions of his past and his actions. "15

Thus, Oedipus never returns home. He fails himself in the journey of "self-discovery" His homecoming is that of the mythical and geographical for a time being, however, not of the sort defined by Heidegger and Nietzche, a return to oneself, a self-knowledge.

\section{HOMECOMING IN THE UNBEARABLE LIGHTNESS OF BEING ACCORDING TO CAMPBELL'S MODEL}

As for Tomas, the protagonist in The Unbearable Lightness of Being, he is torn between his erotic friendships with women which represent the 'lightness' of his life and the constant presence and dependence of Tereza, requiring 'heaviness' on his part. His journey home according to Campbell's model does in a sense take place, however, he takes a bigger step to set home where one might not have considered.

His life with all its lightness is about to move towards heaviness by the arrival of Tereza. Tomas indeed thinks: "How many ancient myths begin with the rescue of an abandoned child! If Polybus hadn't taken in the young Oedipus, Sophocles wouldn't have written his most

15 Frederick Ahl, Sophocles' Oedipus: Evidence and Self Conviction, 73. 
beautiful tragedy." 16 Here, he is implying that "meaning' is created by "myth", that "myth" is a representative of life and has no doubt, roots in rescuing a child.

Tomas welcomes this change -the arrival of a child in the basket, Tereza-, moves towards the heaviness, including letting Tereza be dependant on him, he devises as many meanings as he desires for himself to actualize his journey: "He couldn't very well let a basket with a child in it float down a stormy river! If the Pharaoh's daughter hadn't snatched the basket carrying little Moses from the waves, there would have been no Old Testament, no civilization as we now know it." 17 Thus, he is trying to convince himself that choosing heaviness over lightness is a more plausible choice for him to make. He juxtaposes the image of "civilization" with that of "heaviness" and thereby denotes the distinctness of a life that contains Tereza.

"... he thought happily that he carried his way of living with him as a snail carries his house. Tereza and Sabina represented the two poles of his life, separate and irreconcilable, yet equally appealing." 18

Tereza is stricken by homesickness in Zurich, aware that it is her who weighs Tomas down, decides to return to Prague without Tomas. Tomas is left in a dilemma of leading the semiheaviness ordeal he has decided to go through -his initiation- or to take a rather considerably large step back towards 'lightness' as if no foot was ever set in a journey.

"The realization that he was truly powerless was like the blow of a sledgehammer, yet it was curiously calming as well. No one was forcing him into a decision. He felt no need to stare at the walls of the houses across the courtyard and ponder whether to live with her or not. Tereza had made the decision herself."19

Eventually, it takes him five days to return home in its geographical sense, and only a few days to realize that Prague will not take him in in her arms. We remember that Oedipus has wronged Thebes through his blindness and arrogance, and that was why he eventually did not remain an individual who gets to return home. In the case of Tomas, it is the home itself that is not home anymore, it Prague and the new Communist regime that does not deserve Tomas. He senses the difficulty of returning home, whereas, in Campbell's mythological model, the hero's paramount wish is to be awarded by returning home. Tomas finds it extremely difficult: "Karenin made the homecoming easier by jumping up on him and licking his face." ${ }^{20}$ Has Tomas not accomplished enough in his initiation or is it the home that is merely a home in its geographical sense?

Tomas is back in Prague to protect the 'heaviness', to face the consequences of his political identity which is either retracting his political publication on the condemnation of the Communists or losing his medical license. He ends up resigning forcefully, as at this point he believes that it is on him to embody a modern Oedipus, to accept what he has done and stand by his action.

Tomas is reduced to a window washer and Tereza exhausts herself in bars. This is the life home offers to her loyal children. Eventually comes the moment when Tereza wishes to move away again, and this time Tomas has reached the realization that there exists no home unless they build it.

\footnotetext{
16 Milan Kundera, The unbearable Lightness of Being, 17.

17 Ibid, 15-16.

18 Ibid, 34.

19 Ibid, 32.

20 Ibid, 40.
} 
"Tereza paused and said softly, the best thing to do would be to move away. I agree, said Tomas, but there is nowhere to go." 21

Tomas and Tereza move to the country to live side by side nature. Tomas finds the new home where he has never dreamt of or intended to be home. The new home is home to him because of the presence of Tereza, what has changed the course of his life, the drive that let him set upon the journey, his initiation.

\section{HOMECOMING IN THE UNBEARABLE LIGHTNESS OF BEING ACCORDING TO NIETZSCHE AND HEIDEGGER}

Kundera makes a commentary before delving into the narrative of Tomas and Tereza at the very beginning of The Unbearable Lightness of Being: "In the world of eternal return the weight of unbearable responsibility lies heavy on every move we make. That is why Nietzsche called the idea of eternal return the heaviest of burdens." 22 A few passages ahead, he further clarifies: "The heaviest of burdens is therefore simultaneously an image of life's most intense fulfillment. The heavier the burden, the closer our lives come to earth."23

Tomas has always been in this purgatory of indecisiveness between the lightness and heaviness from the beginning of the novel. Although he seems to have made his peace with the lightness of having no family weighing him down, no woman demanding his wholeness and freedom, he does his best in creating a meaning once Tereza makes her intrusion into his life. He has got to make an association with the image of Tereza at the door and "little Moses" as well as with "Polybus taking in the young Oedipus" as we discussed earlier.

Tomas is struggling with the lightness of life he is experiencing. Not that he does not appreciate his freedom, but at the same time the mental frustration of burdening himself with a life that has no meaning, that can end any second does not leave him in peace.

"Einmal ist keinmal, says Tomas to himself. What happens but once, says the German adage, might as well have not happened at all. If we have only one life to live, we might as well not have lived at all." 24

Although he adores the fact that he is at liberty to spare himself the worries of his previous life -having a dependant wife and child-, the lack of meaningful connection and dependency on others wears him down. That is the driving force that enables him to accept Tereza's arrival in his life. After Tomas and Tereza's marriage and the occupation of Prague by the Russians, Tereza longs to leave Prague as she does not feel home anymore. The way Tomas views and interprets the situation does not merely apply to Tereza's desire to leave Prague, but to his own personal existence as well.

"A person who longs to leave a place where he lives is an unhappy person. That is why Tomas accepted Tereza's wish to emigrate as a culprit accepts his sentence, and one day he and Tereza and Karenin found themselves in the largest city in Switzerland." 25

One is expected to be aware of the implication that Tomas is certainly unhappy with the parameters of his life. And as a person who is concerned with the Nietzschian idea of eternal return, Tomas very well knows that he has got to pave the way for his happiness within himself, which needless to say, has nothing to do with where he lives. Tomas finds it necessary

\footnotetext{
21 Ibid, 246.

22 Ibid, 7.

23 Ibid, 9.

24 Ibid, 14.

25 Ibid, 32.
} 
to reach a state of life that is worth repeating innumerable times. He is on the way of turning himself into a Nietzschian-Heideggerian "Convalescent".

Not only does he set a foot in this initiation on a personal level, but as a political being as Aristotle states: "Hence, it is evident that the state is a creation of nature, and that man is by nature a political animal. And he who by nature and not by mere accident is without a state is either above humanity or below it; he is the 'Tribeless, lawless, heartless one,' whom Homer denounces -the outcast who is a lover of war; he may be compared to a bird which flies alone." 26 Thus, Tomas is indeed on the verge of his personal initiation.

Johan Degenaar remarks: “.. Tomas uses the Oedipus myth to criticize the Russian occupation of his country. The Russians are raping Prague, but they lack the morality of Oedipus to admit their guilt and follow his example by putting out their eyes."27 Tomas accomplishes becoming a politically-aware and responsible citizen by condemning the communist regime taking over his country.

"When Tomas heard Communists shouting in defense of their inner purity, he said to himself, as a result of not knowing, this country has lost its freedom, lost it for centuries, perhaps, and you shout that you feel no guilt? How can you stand the sight of what you've done? How is it you aren't horrified? Have you no eyes to see? If you had eyes, you would have to put them out and wander away from Thebes!"28

He makes an analogy between Dubcek ${ }^{29}$, and Oedipus in regard to the responsibility one takes and the other blames the lack of knowledge. Tomas publishes a paper based on this analogy to condemn Alexander Dubcek of giving in to the Russian Communists. Tomas is a believer in man's freedom of choice and the responsibility it brings consequently.

"... whether they knew or didn't know is not the main issue; the main issue is whether a man is innocent because he didn't know. Is a fool on throne relieved of all responsibility merely because he is a fool?"30

Here, whether consciously or unconsciously, Tomas is setting a trial up for himself as well. He is calling on himself to hold the responsibility of what he does and what he refrains from. For Tomas, 'not knowing' is no legitimate way out.

As a result of being a responsible human being who makes his own choices and voices his political views, Tomas is in the hazard of losing his job as a surgeon in Prague. He resolves to move to Zurich, not only for his own sake but for the of Tereza's serenity as well. After a while in Zurich, Tomas not only has Tereza by his side but picks up his relationship with Sabina as well. He literally has no need to return home. His life is built by all means in Zurich. His initiation has turned into a familiar way of living, the one he used to lead back in home.

He gets to resume his erotic friendship with Tereza in Zurich, to have a secure job that matches his talents and specialties, and he has a semi-happy Tereza by her side, as the narrator states: "Tereza and Sabina represented the two poles, separate and irreconcilable, yet equally appealing." ${ }^{31}$ And yet, once Tereza decides to move back to Prague, Tomas leaves Zurich, says a

\footnotetext{
${ }^{26}$ Aristotle, The Politics of Aristotle, translated with an Introduction, Marginal Analysis, Essays, Notes, and Indicates by B. Jowett (Oxford: Clarendon Press: 1885) 2vols, Vol. 1, 579.

27 Johan Degenaar, The unbearable Lightness of Being-a Philosophical Exploration, 58.

28 Ibid, 179.

${ }^{29}$ Alexander Dubcek, the first secretary of the central committee of the Communist party in Czechoslovakia

30 Milan Kundera, The unbearable Lightness of Being, 181.

31 Ibid, 33.
} 
rather hasty farewell to his newfound freedom: "He was on his way back to the bachelor life, the life he had once felt destined for, the life that would let him be what he actually was." 32 in no time to rejoin Tereza.

Along with making the decision to return to Prague, Tomas unravels the mysterious essence of his life. He gradually succeeds in stepping within rather than without.

"The weighty resolution is at one with the voice of fate; necessity, weight, and value are three concepts inextricably bound: only necessity is heavy, and only what is heavy has value." ${ }^{\prime 3}$

As a result of him taking the responsibility of criticizing the Communist regime, he loses his job as a surgeon. Let us not neglect the fact that he had considered being a surgeon a substantial part of who is was, his identity. And on the verge of getting a step closer to himself he realizes that he is to rid himself of whatever part he owns that is not authentically and essentially attached to his being, he is to remain without a mission.

“... What remains of life when a person rejects what he previously considered his mission." 34

The loss of essence and meaning his job has brought to him vanished, and instead, he gains a state of liberty at which he has all the means to revert to women once again, and this time an innumerable number of them. "In pursuit of knowledge, epic womanizers (and of course Tomas belonged in their ranks) turn away from conventional feminine beauty, of which they quickly tire, and inevitably end up as curiosity collectors." ${ }^{35}$ At least now he realizes his inner motive for the pursuit of women. Once he is asked to sign a petition to engage in the new political act against Communist, he refuses. The reason, no doubt does not relate to him not being a political being, rather, not being his essence and mission.

"Why even think about whether to sign or not? There was only one criterion for all his decision: He must do nothing that could harm her. Tomas could not save political prisoners, but he could make Tereza happy. He could not even succeed in doing that. But if he signed the petition, he could be fairly certain that she would have more frequent visits from undercover agents, and that her hands would tremble more and more." 36

Tomas is finally arriving at the station, at which he awaits no train, as he is the conductor himself. Day by Day, he realizes the nature and essence of love he has for Tereza.

"It was much more important to dig a half-buried crow out of the ground, he said than to send petitions to the president." ${ }_{37}$

Let us note that the reason he is refraining from engaging in a new political act is not due to his intellectual ability, but his very own will to act only based on what necessitates his initial and most basic existence, the one true element that he cannot do without and still exist.

As we discussed before, Tomas gets to a point where he has no doubt there is nowhere to go, implying that the real place to go which is one and merely one for a single being is within themselves. O'Donoghue speaks of the matter: “On the other hand, the philosophical problem

\footnotetext{
32 Ibid, 42.

33 Ibid, 44.

34 Ibid, 205.

35 Ibid, 211.

36 Ibid, 233.

37 Ibid, 31.
} 
which homelessness poses for modernity stems not from a descent of the soul into the dark cave of the world or into the vale of tears but rather from a loss of values or more precisely a loss of meaning and purpose." 38

Tomas finds the 'necessity' of his life. Not every human being gets this far. In other words, not every soul achieves the self-awareness they would ideally desire to gets them closer to becoming an authentic being, that is to becoming themselves. George Steiner interprets what Heidegger has defined as 'homecoming': "'Homecoming' is both the process and goal of authentic being." ${ }^{39}$ The degree to which Tomas sees and interprets the phenomena that surround him is of a very high stance. He thinks and acts straightforwardly, specifically when it involves himself. He asks himself: "...Is it better to shout and thereby hasten the end, or to keep silent and gain thereby a slower death?" 40 His response to the rhetorical question seems unnecessary.

Once one gets to find what it is that makes their essence, that makes them an authentic being, they have succeeded in placing themselves in the status of which they can say they are ready to innumerably repeat the same cycle of life.

The "meaning and purpose" Donoghue discusses do not come in a package, not to Tomas, nor to any human being. Tomas has his doubts from time to time. After he is back in Prague from Zurich, he admonished himself for returning repeatedly, until Tereza tells him of her dream: "I was buried... I'd been buried for a long time. You came to see me every week. Each time you knocked at the grave, and I came out. My eyes were full of dirt. ... I'd say I can't see anyway. I have holes instead of eyes." 41 This recount shakes Tomas undoubtedly, it brings him a final peace, a final reason, a final purpose not merely for why he has returned to Zurich, but to his existence.

"He had never heard anything more harrowing. Holding her tightly in his arms and feeling her body tremble, he thought he could not endure his love."42

It is at this moment that he realizes he is ready to live his life innumerable times were a demon to steal after him: "And he knows that time and again he will abandon the house of his happiness, time and again abandon his paradise and the woman from his dream... to go off with Tereza, the woman born of six laughable fortuities." 43 He does not need the ideal woman of his dream anymore, he has found the real woman. At the very end of the novel, love is juxtaposed with heaviness. However, what distinguished this heaviness from the one Tomas is concerned with at the beginning of the novel is the new one's homeliness.

"Tereza and Tomas had died under the sign of weight. She wanted to die under the sign of lightness. She would be lighter than air. As Parmenides would put it, the negative would change into the positive." 4

The home they found and founded embraced Tomas with his new-founded heaviness, his "Es muss sein" 45 .

\footnotetext{
38 Brendon O'Donoghue, A Poetics of Homecoming: Heidegger, Homelessness and homecoming Venture, (New Castle: Cambridge Scholars Publishing, 2011), 22.

${ }^{39}$ George Steiner, Martin Heidegger, (Chicago: University of Chicago Press, 1991), 44.

${ }^{40}$ Milan Kundera, The unbearable Lightness of Being, 234.

41 Ibid, 242.

42 Ibid, 242.

43 Ibid, 255.

44 Ibid, 290.

45 In German: "It must be.", which referes to the essence and the essential. The one element that its existence is necessitated by the existence of Tomas.
} 


\section{THE JOURNEY ENDS AND BEGINS: CONCLUSION}

Ultimately, Tomas decides to stay loyal to Tereza, not to retract his critical article, to lose his job, to wash windows, and to leave the city behind, and to lead a simple life on a farm. His journey towards himself comes to an end. His journey is over when he eliminates any geographical sense of home and homeliness. Tomas does reach a certain stage where he takes the steering wheel of his life in hand as opposed to Oedipus. However, I am not suggesting that what he does is based on an ideal reading of himself and his situation as Ahl states: "The unbearable Lightness of Being can be read as intertextual sign marking or highlighting the dangers inherent in any interpretative gesture which assumes one version of history or political reality to be the truth." 46 He builds and chooses who he is to the best of his knowledge.

On his journey home, Tomas tells himself: "Love lies beyond Es muss sein!" 47 He believes love is beyond the necessity of his being, bigger than anything he has ever experienced and identified with. Further on the narrator explains: "...he has just discovered the solution to all riddles, the key to all mysteries, a new utopia, a paradise: a world where man is excited by seeing a swallow and Tomas can love Tereza without being disturbed by the aggressive stupidity of sex." 48 Is it not the riddle Tomas' inner Sphinx has posed for him, left unriddled for years in his subconscious. It is at this moment that he finds the key to his homelessness, to his homeliness, to his existence. He can go home now and does so innumerable time to come, only not followed by a demon, rather a peacefulness, a complete heaviness that does not burden, yet frees him.

\section{BIBLIOGRAPHY}

Ahl, Frederick. Sophocles' Oedipus: Evidence and Self Conviction, London: Cornell University Press, 1991.

Aristotle, The Politics of Aristotle, Volume I, trans. and with an Introduction, Marginal Analysis, Essays, Notes, and Indicates by B. Jowett. Oxford: Clarendon Press, 1885.

Campbell, Joseph. The Hero With a Thousand Faces. Princeton: Princeton University Press, 1949.

Degenaar, Johan. "The unbearable Lightness of Being-a Philosophical Exploration in Literator", in Journal of Literary Criticism, Comparative Linguistics and Literary Studies, Vol. III, Nov. 1992: 56-69.

Griffith, R. Drew. "Asserting Eternal Providence: Theodicy in Sophocles' “Oedipus the King”, in Illinois Classical Studies, Volume 17, No.2, Champaign: University of Illinois Press: 1992: 193-211.

Heidegger, Martin. Nietzsche, Vol II, trans. by David Farrell Krell, San Francisco: Harper Collins, 1979-1987.

Kundera, Milan The unbearable Lightness of Being, trans. by Michael Henry Heim, London: Faber \& Faber: 2015.

Nietzsche, Friedrich. The Gay Science, trans. by Walter Kaufmann New York: Vintage Books, 1974.

O’Donoghue, Brendon. A Poetics of Homecoming: Heidegger, Homelessness and homecoming Venture New Castle: Cambridge Scholars Publishing, 2011.

Olsen, Stein Haugom. "The Meaning of a Literary Work” in New Literary History, Problems of Literary Theory, Volume 12, No. 1, Baltimore: John Hopkins University Press, 1982: 13-32.

Reesman, Jeanne Campbell., Willingham, John R., Morgan, Lee., Labor, Earle., Guerin, Wilfred L., A Handbook of Critical approaches to Literature, New York: Oxford University Press, 2005.

Sophocles, Oedipus The King, trans. by Dudley Fitts and Robert Fitzgerald, California: Harcourt Inc., 1977.

Steiner, George. Martin Heidegger, Chicago: University of Chicago Press, 1991.

${ }^{46}$ Frederick Ahl, Sophocles' Oedipus: Evidence and Self Conviction, 81.

47 Milan Kundera, The unbearable Lightness of Being, 254.

48 Ibid, 255. 